\title{
KEEFEKTIFAN BIMBINGAN KELOMPOK TERHADAP PENINGKATAN MOTIVASI BERWIRAUSAHA SISWA KELAS X SMK NEGERI 1 MADIUN TAHUN PELAJARAN 2010/2011
}

\author{
Hery Bagus Anggoro Wicaksono,
}

\begin{abstract}
Abstrak
Penelitian ini bertujuan untuk mengetahui keefektifan bimbingan kelompok terhadap peningkatan motivasi berwirausaha siswa kelas X SMK Negeri I Madiun.

Populasi penelitian sebanyak 623 siswa kelas X SMK Negeri 1 Madiun Teknik sampling yang digunakan adalah porposive sampling dengan ukuran sampel sebanyak 32 siswa. Pengumpulan data dengan menggunakan skala psikologis dan dianalisis secara kuantitatif dengan uji t sampel berkorelasi dan uji t sampel independent.

Hasil penelitian menunjukkan bahwa motivasi berwirausaha kelompok eksperimen menunjukkan motivasi berwirausaha sangat tinggi $0 \%$, motivasi berwirausaha tinggi $43,75 \%$, motivasi berwirausaha sedang $25 \%$, motivasi berwirausaha rendah $25 \%$, dan motivasi berwirausaha sangat rendah 6,25\% Sedangkan kelompok kontrol menunjukkan motivasi berwirausaha sangat tinggi 0 $\%$, motivasi berwirausaha tinggi $37,5 \%$, motivasi berwirausaha sedang $25 \%$, motivasi berwirausaha rendah $25 \%$, dan motivasi sangat rendah 12,5\%. Motivasi berwirausaha pada kelompok eksperimen hasil pre tes lebih rendah dibanding dengan hasil post tes yang menunjukkan skor tertinggi ada selisih 25, skor terendah selisih 9 untuk pre test lebih rendah, skor mean ada selisih 22,06 untuk sebelum perlakuan lebih rendah. Data tentang motivasi berwirausaha pada kelompok kontrol hasil pretes lebih rendah dibanding dengan hasil post tes yang menunjukkan skor tertinggi ada selisih 3 untuk pretest lebih rendah, skor terendah selisih 2 untuk pre test lebih rendah, skor mean ada selisih 1,69 untuk sesudah post test lebih rendah.

Saran untuk SMK Negeri I Madiun hendaknya menambah fasilitas pendukung layanan bimbingan dan konseling dalam memberikan layanan bimbingan kelompok terhadap peningkatan motivasi berwirausaha sehingga siswa dapat mempunyai pemahaman yang luas terhadap motivasi berwirausaha.
\end{abstract}

Kata Kunci : bimbingan kelompok, motivasi berwirausaha

\section{Pendahuluan}

Kemajuan berpikir dan kesadaran manusia akan diri dan dunianya telah mendorong terjadinya globalisasi. Situasi global membuat kehidupan semakin 
kompetitif dan membuka peluang bagi manusia untuk mencapai status dan tingkat kehidupan yang lebih baik. Anwar (2006: 13) mengemukakan dampak positif dari kondisi global telah mendorong manusia untuk terus berfikir mengadopsi dan menerapkan inovasi yang datang dari luar untuk meningkatkan peluang kesempatan kerja bagi masyarakat, pengaruh global dapat mendidik masyarakat untuk memiliki pola pikir kosmopolitan dan pola tindak kompetitif, suka bekerja keras, mau belajar untuk meningkatkan ketrampilan, prestasi kerja dan meningkatkan kemampuan serta tidak puas terhadap apa yang dicapainya pada saat ini. Jalal (2001: 59) mengemukakan dampak negative globalisasi memberikan peluang bagi penetrasi budaya asing ke dalam masyarakat Indonesia yang berlangsung dalam tempo yang cepat dan dapat mengubah watak bangsa.

Pendidikan nasional berfungsi mengembangkan kemampuan dan membentuk watak serta peradaban bangsa yang bermartabat dalam rangka mencerdaskan kehidupan bangsa, bertujuan untuk berkembangnya potensi siswa agar menjadi manusia yang beriman dan bertakwa kepada Tuhan Yang Maha Esa, berakhlak mulia, sehat, berilmu, cakap, kreatif, mandiri, dan menjadi warga negara yang demokratis serta bertanggung jawab (UU NO. 20 Tahun 2003). Untuk mewujudkan visi dan misi pendidikan tersebut pembenahan di sector pendidikan perlu dilakukan oleh pemerintah. Sebenarnya pemerintah telah mengambil berbagai kebijakan dalam pembenahan di sektor pendidikan ini diantaranya adalah 1) pemerataan dan perluasan akses pendidikan,2) peningkatan mutu, 3) relevansi dan daya saing dan 4) akuntabilitas dan pencintraan public. Sedikit demi sedikit kebijakan tersebut sebenarnya juga telah memberi dampak 
yang signifikan dalam perbaikan pendidikan di Indonesia, namun demikian tidak bisa dipungkiri permasalah terkait dengan pendidikan silih berganti muncul, seperti rendahnya SDM yang dihasilkan oleh dunia pendidikan. Permasalahan ini muncul diantaraanya disebabkan belum adanya relevansi antara dunia pendidikan dan dunia kerja, konsep link and match yang dicanangkan pemerintah sejak puluhan tahun silam ternyata belum mampu mengatasi permasalahan terkait dengan tenaga kerja di Indonesia. Hal ini ditunjukkan masih banyaknya lulusan dari dunia pendidikan yang mengganggur. Padahal dalam PP No.19 tahun 2005 juga telah ditegaskan bahwa pendidikan di SMK bertujuan untuk memenuhi Standar kompetensi lulusan pada satuan pendidikan menengah kejuruan bertujuan untuk meningkatkan kecerdasan, pengetahuan, kepribadian, ahklak mulia, serta keterampilan untuk hidup mandiri dan mengikuti pendidikan lebih lanjut sesuai dengan kejuruannya. Kewirausahaan termasuk salah satu unsur yang harus ditambahkan, selain pelajaran normatif dan produktif lainnya. Meskipun ilmu tentang kewirausahaan tak cukup hanya diajarkan di bangku sekolah, namun setidaknya ilmu tersebut harus sudah mulai ditanamkan sejak tingkat sekolah tingkat menengah dan mulai diaplikasikan melalui praktik langsung di lapangan (http://www.pasfmpati.com)

Berdasarkan tujuan pendidikan di SMK tersebut di atas, secara eksplisit mengemukakan pentingnya kewirausahaan ditumbuhkan dalam diri siswa. Bahkan dikatakan, bahwa kewirausahaan merupakan komponen inti dari tujuan pendidikan nasional, namun pada kenyataannya usaha agar siswa memiliki sifat kewirausahaan belum mendapat perhatian khusus dalam kurikulum SMK. Di lain 
pihak tamatan SMK dimaksudkan untuk memasuki lapangan kerja tingkat menengah, akan tetapi berbeda dengan kenyataan dilapangan yang menunjukan bahwa sebagian besar tamatan SMK ternyata berusaha melanjutkan pendidikan ke perguruan tinggi, sebagian lagi berusaha bekerja mandiri dan sisanya menganggur atau menjadi tenaga yang kurang produktif.

Permasalahan-permasalah tersebut mengindikasikan bahwa goal oriented dari pendidikan kita adalah terserapnya lulusan di dunia kerja. Sementara itu penanaman mental pada lulusan SMK untuk mampu berkarya dengan menciptakan lapangan pekerjaan atau berwirausaha kurang optimal untuk dikembangkan. Hal ini ditunjukkan dengan adanya permasalahan terkait dengan motivasi berwirausaha siswa SMK. Pada Agustus 2008, tingkat pengangguran terbuka atau TPT masih didominasi oleh yang berpendidikan setingkat SMA ke atas, namun cenderung menurun. Menurut Badan Pusat Statistik (BPS) menunjukkan bahwa lulusan SMK masih mendominasi TPT. (http://www.inaplas.org/index.)

Kondisi tersebut ternyata juga dijumpai di SMK Negeri 1 Madiun, berdasarkan hasil observasi dan wawancara yang telah dilakukan oleh peneliti pada bulan Mei 2010 dengan guru BK di sekolah tersebut. Dapat disimpulkan bahwa masih banyak siswa lulusan SMK Negeri 1 Madiun yang menggantungkan nasibnya pada program bursa kerja khusus sekolah. Hal tersebut ditunjukan dengan banyaknya alumni dari sekolah tersebut yang datang kesekolah untuk ikut seleksi merebutkan peluang kerja yang ada di BKK sekolah. 
Upaya yang perlu dilakukan untuk menumbuhkan motivasi berwirausaha tersebut salah satu cara yang dapat dilakukan dengan mengoptmalkan peran bimbingan dan konseling di SMK. Untuk itu Bimbingan dan Konseling di SMK hendaknya tidak hanya sekedar mengidentifikasi potensi siswa, memberikan bimbingan pengenalan diri dan dunia kerja akan tetapi seyogyanya menyentuh tujuan hidup (life goals), membantu siswa agar mampu melihat kehidupan aktual setelah tamat (life work) mereka secara keseluruhan. Menumbuhkan, menyentuh dan mengembangkan sifat, jiwa dan kebiasaan berwirausaha yang sangat diperlukan siswa perlu dilakukan oleh guru BK, sehingga setelah lulus siswa mampu menghadapi persaingan yang semakin keras dimasa yang akan datang.

Salah satu layanan bimbingan konseling yang diduga mampu meningkatkan motivasi berwirausaha adalah layanan bimbingan kelompok. Dipilihnya layananan bimbingan kelompok sebagai alternative untuk meningkatkan motivasi berwirausaha dengan pertimbangan bahwa bimbingan kelompok adalah kegiatan yang diorganisasikan untuk mencegah perkembangan masalah yang isi utamanya meliputi informasi pendidikan, pekerjaan, pribadi dan masalah sosial yang tidak disajikan dalam bentuk pelajaran. Oleh karena itu penelitian ini ingin mencoba mengetahui kefektifan layanan Bimbingan Kelompok terhadap peningkatkan motivasi berwirausaha.

\section{Metode Penelitian}

Dilihat dari segi pendekatan yang digunakan, penelitian ini merupakan penelitian kuantitatif karena menekankan fenomena-fenomena yang obyektif dan dikaji secara kuantitatif. Untuk memaksimalkan obyektivitasnya dengan 
menggunakan angka-angka dan pengolahan statistik. Penelitian ini juga termasuk penelitian eksperimen tidak murni atau eksperimental semu dengan menggunakan rancangan Non Randommized Control group Pre Test Post Test Design, maka ada dua kelompok yaitu kelompok eksperimen dan kelompok kontrol. Kelompok eksperimen adalah kelompok yang diberi perlakuan, sedangkan kelompok kontrol merupakan kelompok pembanding terhadap perlakukan yang diberikan kelompok eksperimen. Perlakuan yang dilakukan oleh peneliti terhadap kelompok eksperimen adalah dengan memberikan layanan bimbingan kelompok. Teknik pengambilan sampel dalam penelitian ini yaitu dengan menggunakan teknik nonprobabilitas dengan cara memilih sampel berdasarkan jatah yang telah ditentukan atau porposive sampling.

Sehubungan dengan jenis data yang akan dikumpulkan adalah data tentang motivasi kewirausahaan dengan sumber data siswa maka instrumen yang digunakan dalam penelitian ini dengan menggunakan skala psikologis dengan pertimbangan data yang diungkap berupa data konstrak atau konsep psikologis. Sehubungan dengan itu, maka dalam penelitian ini skala psikologis yang digunakan dengan memodifikasi skala model Likert.

Skala psikologis ini dikembangkan oleh peneliti sendiri, untuk skala motivasi berwirausaha dikembangkan berdasarkan pendapat Shane, (2003 : 263268) dan skala penilaian bimbingan kelompok dikembangkan berdasarkan pendapat Prayitno, (1995: 44-60) dengan langkah-langkah sebagai berikut : (1) merumuskan definisi operasional dari definisi konseptual masing-masing variabel penelitian; (2) menjabarkan definisi operasional menjadi indikator-indikator 
masing-masing variabel penelitian; (3) dari indikator-indikator yang telah tersusun, kemudian masing-masing indikator di jabarkan dalam item/butir-butir pernyataan. Oleh karena itu skala psikologis yang digunakan dalam penelitian ini disebut dengan skala motivasi berwirausaha dan penilain bimbingan kelompok, karena skala ini mengungkap tentang motivasi berwirausaha dan bimbingan kelompok.

Validitas instrumen dalam penelitian ini digunakan logical validity dan content validity. Pengujian validitas logik dilakukan dengan analisis faktor dengan cara menghitung koefisien korelasi (r) antara skor butir dengan skor total. Kriteria yang dijadikan dasar untuk melihat valid tidaknya sebuah butir instrumen adalah dengan melihat besarnya nilai koeefisien validitas ( $\mathrm{r}$ ) antara skor butir dengan skor total dengan ketentuan, apabila nilai " $r$ " >0,3 berarti nomor butir tersebut dinyatakan valid. Hal ini juga dipertegas oleh Cronbach (1970 : 429 dalam Azwar 2003:103) yang menyatakan bahwa koefisien yang berkisar antara 0.30 sampai dengan 0.50 telah dapat memberikan kontribusi yang baik terhadap efisiensi suatu lembaga pelatihan.

Hasil uji skala motivasi berwirausaha menunjukkan bahwa koefisien korelasi validitas ( $\mathrm{r}$ ) bergerak antara $-0,142$ sampai dengan 0.808 . Sedangkan hasil penghitungan uji validitas pada skala penilaian bimbingan kelompok terhadap 40 item pernyataan menunjukkan korelasi item total (r) bergerak antara 0.232 sampai dengan 0.696. Dari 40 item pernyataan didapatkan 38 item dinyatakan valid karena koefisien korelasi validiatas di atas 0.30 atau $r$ hitung $>r$ tabel yaitu 0.3 , sedangkan 2 item pernyataan dinyatakan tidak valid karena $\mathrm{r}$ 
hitung < r tabel. Berdasarkan hasil tersebut, maka item yang tidak valid diperbaiki dan digunakan untuk mengungkap data. Analisa data penelitian ini mengunakanan analisis kuantitatif untuk menguji hipotesisnya digunakan uji $\mathrm{T}$ dan menghitung sumbangan efektif bimbingan kelompok menggunakan regresi sederhana.

\section{Hasil Penelitian}

Analisis persentase hasil pre test motivasi berwirausaha kelompok eksperimen menunjukkan motivasi berwirausaha sangat tinggi 6,25\%, motivasi berwirausaha tinggi $25 \%$, motivasi berwirausaha sedang 31,25\%, motivasi berwirausaha rendah $37,5 \%$, dan mempunyai motivasi berwirausaha sangat rendah $0 \%$.

Sedangkan analisis persentase hasil pre test setiap indikator motivasi berwirausaha kelompok kontrol menunjukkan motivasi berwirausaha sangat tinggi $0 \%$, motivasi berwirausaha tinggi $43,75 \%$, motivasi berwirausaha sedang $31,25 \%$, motivasi berwirausaha rendah $12,5 \%$, dan mempunyai motivasi berwirausaha sangat rendah $12,5 \%$.

Analisis persentase hasil post test motivasi berwirausaha kelompok eksperimen menunjukkan motivasi berwirausaha sangat tinggi $0 \%$, motivasi berwirausaha tinggi $43,75 \%$, motivasi berwirausaha sedang $25 \%$, motivasi berwirausaha rendah $25 \%$, dan motivasi berwirausaha sangat rendah 6,25\%

Sedangkan analisis persentase hasil post test motivasi berwirausaha pada kelompok kontrol menunjukkan motivasi berwirausaha sangat tinggi $0 \%$, motivasi berwirausaha tinggi $37,5 \%$, motivasi berwirausaha sedang $25 \%$, motivasi berwirausaha rendah $25 \%$, dan motivasi sangat rendah $12,5 \%$. 
Data tentang motivasi berwirausaha pada kelompok kontrol hasil pre tes lebih rendah dibanding dengan hasil post tes yang menunjukkan skor tertinggi ada selisih 3 untuk pre test lebih rendah, skor terendah selisih 2 untuk pre test lebih rendah, skor mean ada selisih 1,69 untuk sesudah post test lebih rendah.

Hasil analisis data pre test, motivasi berwirausaha pada kelompok eksperimen dan kelompok kontrol menunjukkan bahwa $\mathrm{t}_{\text {hitung }}=-4,712<\mathrm{t}_{\text {tabel }}=$ 2,04 berarti tidak ada perbedaan yang signifikan.

Hasil analisis data post test, motivasi berwirausaha pada kelompok eksperimen dan kelompok kontrol menunjukkan bahwa $t_{\text {hitung }}=0,656<t_{\text {tabel }}=2.04$ berarti tidak ada perbedaan yang signifikan.

Uji Selisih motivasi berwirausaha pre test \& post test kelompok eksperimen dengan kelompok kontrol menunjukkan bahwa $\mathrm{t}_{\text {hitung }}=5,368>\mathrm{t}_{\text {tabel }}=$ 2.04 berarti ada perbedaan yang signifikan

Hasil analisis data pre test dan post test motivasi berwirausaha pada kelompok eksperimen menunjukkan bahwa $t_{\text {hitung }}>t_{\text {tabel }}$ atau $t_{\text {hitung }}=12,123>t_{\text {tabel }}$ $=2,04$ berarti ada perbedaan yang signifikan antara sebelum dan sesudah diberi layanan bimbingan kelompok untuk meningkatkan motivasi berwirausaha. Maka hipotesis kerja bisa diterima.

Hasil analisis data pre test dan post test motivasi berwirausaha pada kelompok kontrol menunjukkan bahwa $\mathrm{t}_{\text {hitung }}<\mathrm{t}_{\text {tabel }}$ atau $\mathrm{t}_{\text {hitung }}=-0,077<\mathrm{t}_{\text {tabel }}=$ 2,04 berarti tidak ada perbedaan yang signifikan. Maka hipotesis kerja tidak bisa diterima. 
Hasil analisis tentang keefektifan layanan bimbingan kelompok terhadap peningkatan motivasi berwirausaha, di atas didukung oleh data perbandingan perubahan skor rerata dari masing-masing kelompok pre test dan post test. Perubahan ada pada tabel di bawah ini:

\section{Perubahan Mean Motivasi berwirausaha}

\begin{tabular}{|l|c|c|r|}
\hline \multirow{2}{*}{ Kelompok } & \multicolumn{2}{|c|}{ Mean } & \multirow{2}{*}{ Perubahan } \\
\cline { 2 - 3 } & Pre test & Post test & \\
\hline Eksperimen & 334.25 & 356.31 & 22,06 \\
\hline Kontrol & 354.50 & 352,81 & $-1,69$ \\
\hline
\end{tabular}

Pada tabel di atas tampak bahwa adanya perubahan yang sangat besar mean motivasi berwirausaha pada kelompok eksperimen dibandingkan dengan kelompok kontrol. Jadi siswa yang mendapat perlakuan diberi layanan bimbingan kelompok menunjukkan tingkat motivasi berwirausaha yang lebih besar dibanding siswa yang tidak mendapatkan perlakuan berupa layanan bimbingan kelompok, terbukti.

Nilai $R^{2}$ ( R Square) menunjukan bahwa $83,4 \%$ dari variance motivasi berwirausaha dapat dijelaskan oleh perubahan dalam variabel penilaian bimbingan kelompok. Mengindikasikan bahwa regresi secara statistik sangat signifikan dengan nilai $\mathrm{F}=70.413$ untuk derajat kebebasan $\mathrm{k}=1$ dan $\mathrm{n}-\mathrm{k}-1=16-1-1=$ 14 dan P-value $=0,000$ yang jauh lebih kecil dari $\alpha=0,05$.

Uji F $\beta_{1}=0$ terhadap $H_{1}: \beta_{1} \neq 0$ dari perhitungan tersebut bahwa $H_{0}$ ditolak karena $\mathrm{P}$-value $=0,000$ dimana lebih kecil dari $\alpha=0,05$ sehingga 
persamaan garis regresi menggunakan metode kuadrat terkecil yang didapat adalah:

$$
\hat{y}=38,533+1,939 x
$$

Di mana:

$\widehat{y}=$ skor motivasi berwirausaha

$\mathrm{X}=$ bimbingan kelompok

\section{Pembahasan}

Berdasarkan deskripsi hasil penelitian diperoleh dua variabel yaitu layanan bimbingan kelompok dan peningkatan motivasi berwirausaha, termasuk dalam kategori ini berarti bahwa sebagian besar siswa kelas X SMK Negeri I Madiun mempunyai motivasi berwirausaha yang rendah. Keadaan tersebut pada dasarnya erat kaitannya dengan keadaan lingkungan sekolah yang menunjang di SMK Negeri I Madiun yaitu tingkat persaingan mencari kerja (hasil survey di lapangan) sehingga menumbuhkan motivasi tersendiri untuk berwirausaha.

Hasil penelitian sejalan dengan pendapat Gazda dalam Wibowo (2005: 17) menyimpulkan bahwa bimbingan kelompok diorganisasikan untuk mencegah perkembangan masalah, yang isi utamanya meliputi informasi pendidikan, pekerjaan, pribadi dan masalah sosial yang tidak disajikan dalam bentuk pelajaran.

Hasil penelitian menunjukkan bahwa motivasi berwirausaha pada kelompok eksperimen yang mendapat perlakuan berupa layanan bimbingan kelompok untuk meningkatkan motivasi berwirausaha dibandingkan dengan kelompok kontrol yang tidak mendapat perlakuan layanan bimbingan kelompok 
untuk meningkatkan motivasi berwirausaha menunjukkan adanya perbedaan yang signifikan. Dari skor rerata yang diperoleh masing-masing kelompok tersebut ternyata skor rerata perubahan motivasi berwirausaha, sesudah mendapat perlakuan layanan layanan bimbingan kelompok untuk meningkatkan motivasi berwirausaha hasilnya lebih meningkat.

Wibowo (2005: 17) menyatakan bahwa bimbingan kelompok adalah suatu kegiatan kelompok dimana pimpinan kelompok menyediakan informasi-informasi dan mengarahkan diskusi agar anggota kelompok menjadi lebih sosial atau untuk membantu anggota-anggota kelompok untuk mencapai tujuan-tujuan bersama.

Layanan bimbingan kelompok untuk meningkatkan motivasi berwirausaha siswa kelas X SMK Negeri I Madiun bertujuan memberikan pemahaman kepada siswa yang terkait dengan motivasi berwirausaha yang digunakan sebagai alat untuk menumbuhkan dan mengembangkan motivasi berwirausaha.

Hasil penelitian tentang layanan bimbingan kelompok untuk meningkatkan motivasi berwirausaha yang diberikan kepada kelompok eksperimen menunjukkan skor yang lebih tinggi dari pada kelompok kontrol yang tidak diberi layanan bimbingan kelompok untuk meningkatkan motivasi berwirausaha, hal ini dikarenakan motivasi berwirausaha perlu ditumbuhkan, dikembangkan dan ditingkatkan sehingga memberikan kesan yang diterima siswa lebih konkrit dan riil, sehingga membuat siswa menjadi termotivasi berwirausahanya untuk memuwujudkan motivasinya yang ditandai dengan semangat yang muncul dari dalam diri sendiri, mampu menetapkan tujuan antara yang terukur dan spesifik, 
mengenali kekuatan dan keterbatasan diri maupun lingkungan, tidak berhenti sebelum mendapatkan keberhasilan.

Motivasi berwirausaha siswa yang tinggi setelah menerima layanan bimbingan kelompok untuk meningkatkan motivasi berwirausaha sesuai dengan pendapat Zimmerer (2008) Kewirausahaan adalah proses penerapan kreativitas dan inovasi dalam memecahkan persoalan dan menemukan peluang untuk memperbaiki kehidupan.

Karakteristik individu yang memiliki motivasi berwirausaha tinggi menurut Shane (2003 : 263-268), adalah Need for achievement tinggi, berani mengambil resiko, toleransi terhadap ambiguitas, locus of control yang baik, self efficacy, penetapan tujuan yang jelas, kemandirian, dorongan dan memiliki energi tinggi.

Apabila seseorang memiliki ciri - ciri diatas, seseorang itu selalu memiliki motivasi berwirausaha yang cukup kuat, karena motivasi itu sangat penting dalam kehidupannya kelak, sehingga kehidupannya akan lebih baik kalau mereka mempunyai motivasi berprestasi tinggi, berani mengambil resiko yang dihadapi, paham terhadap situasi yang ambigu, mempunyai locus of control yang baik, khususnya internal locus of control, self efficacy yang tinggi, mempunyai tujuan hidup yang jelas, mempunyai kemandirian, dorongan dan memiliki energi tinggi untuk melakukan setiap kegiatan dalam hidupnya. Mereka selalu ingin berprestasi dalam setiap langkah kehidupannya. Mereka berani mengambil keputusan yang terbaik walaupun dalam situasi yang sulit. Mereka berusaha untuk selalu mengerti keberadaan dirinya dalam posisi yang tidak jelas. Mereka percaya 
bahwa keberhaslilan atau kegagalan ditentukan oleh dirinya sendiri. Mereka lebih percaya terhadap kemampuan diri sendiri. Mereka mempunyai standar hidup yang jelas dan terukur. Mereka mempunyai kemandirian dalam menyelesaikan permasalahan yang dihadapi. Mereka mempunyai dorongan untuk selalu melakukan tidakan yang positif dan selalu mempunyai energi tinggi untuk menyelesaikan kerja. Ciri-ciri motivasi seperti itu akan sangat penting dalam penentuan kariernya kelak.

Siswa yang motivasi berwirausahanya meningkat mendorong siswa dalam belajar akan menjadi lebih baik juga, hal ini sesuai dengan hasil penelitian yang menunjukkan bahwa hasil analisis skor motivasi berwirausaha setelah mendapatkan layanan bimbingan kelompok untuk meningkatkan motivasi berwirausaha meningkat lebih tinggi dibandingkan dengan yang tidak mendapatkan layanan bimbingan kelompok untuk meningkatkan motivasi berwirausaha. Siswa yang diberi layanan bimbingan kelompok untuk meningkatkan motivasi berwirausaha menunjukkan bahwa motivasi berwirausahanya meningkat.

\section{Kesimpulan dan Saran}

Berdasarkan pada hasil analisis dan pembahasan penelitian yang peneliti lakukan di SMK Negeri 1 Madiun semester I tahun pelajaran 2010/2011 tentang keefektifan bimbingan kelompok terhadap peningkatkan motivasi kewirausahaan siswa yang menggunakan uji t pada kelompok eksperimen, tingkat motivasi berwirausaha siswa sesudah pre test dan post test menunjukkan bahwa $t_{\text {hitung }}>t_{\text {tabel }}$ atau $\mathrm{t}_{\text {hitung }}=12,123>\mathrm{t}_{\text {tabel }}=2.04$ berarti ada perbedaan yang signifikan. Hipotesis 
kerja berbunyi: Ada keefektifan layanan bimbingan kelompok terhadap peningkatan motivasi berwirausaha pada siswa kelas X SMK Negeri 1 Madiun semester I tahun pelajaran 2010/2011, terbukti kebenarannya, dan hipotesis diterima.

Berdasarkan pada hasil simpulan penelitian, maka saran yang diajukan adalah Kepada Kepala SMK Negeri I Madiun hendaknya menambah fasilitas ruang bimbingan dan jam yang luas kepada guru pembimbing sebagai pendukung layanan bimbingan dan konseling dalam memberikan layanan bimbingan kelompok terhadap peningkatan motivasi berwirausaha siswa, sehingga siswa dapat mempunyai pemahaman yang luas terhadap motivasi berwirausaha. Kepada guru pembimbing diharapkan dapat menggunakan dan memanfaatkan sarana layanan bimbingan kelompok sebagai bentuk intervensi guru pembimbing untuk meningkatkan motivasi berwirausaha siswa sehingga siswa lebih terarah dalam menekuni kompetensi kejuruan yang diambilnya. Kepada peneliti lain, hendaknya hasil penelitian ini dapat digunakan sebagai acuan dalam melakukan penelitian yang sejenis.

\section{Daftar Pustaka}

A.Goswami, Namita Dalmia dan Megha Pradhan. 2008. Entrepreneurship in India. National Knowledge Commission

Anwar. 2006. Pendidikan Kecakapan Hidup.Bandung: Alfabeta.

A. Sutoyo. 2009. Pemahaman Individu : Observasi Checklist, Kuisioner \& Sosiometri. Semarang : CV Widya Karya

Depdikbud. 2003. Undang-undang No. 20.Tahun 2003 tentang Sistem Pendidikan Nasional. Jakarta : Depdikbud. 
.2005. PP No. 19 Tahun 2005 tentang Standar Pendidikan Nasional. Jakarta: Depdikbud

Gamage, Helan Ramya. Cameron dan Woods. 2003. Are Sri Lankan Entrepreneurs Motivated by the Need for Achievement?. $9^{\text {th }}$ International conference on Sri Lanka Studies, 28th - 30th November 2003, Matara, Sri Lanka.

Fasli Jalal dan Supriadi. D. 2001. Reformasi Pendidikan: Dalam Konteks Otonomi Daerah.Yogyakarta: Adicita Karya Nusa

Gladding, Samuel.T. 1995. Group work : A Counseling specialty. New Jersey : Prentice-hall, Inc

J. Saiman. 2009. Kewirausahaan. Jakarta : Salemba Empat

Mungin Edi Wibowo. 2005. Konseling Kelompok Perkembangan. Semarang : UNNES Press.

Mohar Yusof, Sandhu, Manjit, Kamal. 2007. Relationship Between Psychological Characteristics and Entrepreneurial Inclination : A Case Study of Students at University Tun Abdul Razak. Journal of Asia Entrepreneurship and Sustainability. Vol III pp 23-42

Prayitno. 1995. Layanan Bimbingan dan Konseling Kelompok (Dasar dan Profil) Jakarta: Ghalia Indonesia.

Prayitno dan Amti, Erman. 2004. Dasar-dasar Bimbingan dan Konseling. Jakarta: Rineka Cipta

Puji Suci Rahayu. 2009. Peningkatan Kinerja Melalui Orientasi Kewirausahaan, Kemampuan Manajemen, dan Strategi Bisnis (Studi pada Industri Kecil Menengah Bordir di Jawa Timur). Jurnal Manajemen dan Kewirausahaan. VOL.11, NO. 1: 46-58

Raduan Che Rose, Naresh Kumar, Lim Li Yen. 2006. The Dynamics of Entrepreneurs' Success Factors in Influencing Venture Growth. Journal of Asia Entrepreneurship and Sustainability

Saifudin Azwar,. 2005. Tes Prestasi : Fungsi dan Pengembangan Pengukuran Prestasi Belajar. Yogyakarta: Pustaka Pelajar.

2005. Sikap Manusia : Teori dan Pengukurannya. Yogyakarta: Pustaka Pelajar.

2005. Penyusunan Skala Psikologi. Yogyakarta: Pustaka Pelajar.

Scarborough. Zimmerer. Wilson. 2008. Essential of Entrepreneurship and Small business Management, $5^{\text {th }}$ ed. New Jersey : Pearson Education 
Segal,Gerry. Dan Borgia dan Jerry Schoenfeld. 2005. The Motivation to Become An Entrepreneur. International Journal of Entrepreneurial Behaviour \& Research. Vol. 11 No. 1, pp. 42-57

Shane, S, Locke, E. A, Collins, C.J. 2003 : Entrepreneurial Motivation. Human Resourse Management review, Vol 13 pp. 257-279

Sutrisno Hadi. 2004. Metodologi Research. Yogyakarta : Andi Offset.

Sugiyono.2010. Metode Penelitian Pendidikan : Pendekatan Kuantitatif, Kualitatif dan $R \& D$. Bandung : Alfabeta

Sukmadinata, N.S. 2009. Metode Penelitian Pendidikan. Jakarta : PT Remaja Rosdakarya.

Suryana, 2009. Kewirausahaan. Jakarta : Salemba Empat

Wadhwa, Vivek. 2009. The Anatomy of an Entrepreneur : Family Background and Motivation. The Ewing Marion Kauffman Foundation. 